\section{International Scientific Journal Theoretical \& Applied Science}

Jamshed Abdurashidovich Ochilov

Independent Scientific researcher Samarkand State University named after AlisherNavai,

p-ISSN: 2308-4944 (print) e-ISSN: 2409-0085 (online) yaz-81@samdu.uz

Year: $2016 \quad$ Issue: 3 Volume: 35

Published: $30.03 .2016 \quad$ http://T-Science.org

SECTION 30. Philosophy.

\title{
THE ROLE OF TECHNOGEN CIVILIZATION AND FACTORS OF DEALING PERIODS
}

\author{
Abstract: On the following article were complex -systematic analyzed characteristics dynamic changes of \\ objective conditions and system subjective factors, globalization of technogencivilization in context escalation \\ "huge culture" \\ Key words: technogen civilization, globalization, determinalizing factor, human factor, spiritual and moral \\ wealthy, technological derminism, technological culture, escalation "huge culture", entropotechnogen culture, \\ technogenthinking. \\ Language: English \\ Citation: Ochilov JA (2016) THE ROLE OF TECHNOGEN CIVILIZATION AND FACTORS OF \\ DEALING PERIODS. ISJ Theoretical \& Applied Science, 03 (35): 172-175. \\ Soi: http://s-o-i.org/1.1/TAS-03-35-29 Doi: crossef http://dx.doi.org/10.15863/TAS.2016.03.35.29
}

Any historical period, the level of public availability of appropriate technological culture of the emerging trend of social development, as well as man-made form of tsvilizatsiya an important factor in determining the structural element. In fact, of technological culture established.

At any historical periods for the existence rate of the society has created equal technologic culture and counted as internal element and main factor which define of rising technogen civilization and development tendency of society. In fact, the ancient written sources, archaeological findings, the results of ethnographic research in ancient times, people's way of life and its expression associated with the formation of a technological civilization elements are proving that the technologic culture have been developed.

It is true that in early history of mankind: technogen civilization, technological culture, general forces of production, the level of development of the material means, particularly in the labor were defined the character of the socio-economic relations. For example, the primitive technological culture [1] in the everyday level of moral activity: it has an instinctive-reflective character, which was directed prove the utility-economic needs of the society. However, primitive technological culture technological civilization was not influenced to the system of "nature-society-human" relations, because "areal circulation", "social place" was nearly small and few of population.

In other words, the limit of cultural and economic activity of human and also caused the limit in the sphere of influence to the technogen civilization. Because, on the first side, the development characteristics of the force production of technological culture (mainly factors) were originated from the daily natural needs and purposes of society. On the other hand, science, engineering, technology, intellectual potential, which was a result of the development of the "technological human" (the influence to the nature of point of view), had not become the subject of antropotexnogen culture.

The socio-economic life of the people in the first primitive "technically cultural influence" method is belonged to the Neolithic period, or 5-8 centuries earlier period. In fact, in this period human labor was differentialzed, formation of agriculture and livestock was determined brief couture of technogen civilization or "architecture". That is, science directions which study characteristics of technogen civilization equal for the sphere of the first labor of human in socio-economic activity and lifestyle(even it was simple).

The changes of characters (as a relatively independent social phenomenon)of adequate economic production method has been base for the development technological culture. Especially, the occurrence of a major division of labor in the 
production of technological culture and their tools and methods of transformalizing system were developed. For example, technological culture of its period: farming, husbandry, veterinary culture of practical experience and propaganda of "Avesta" holy book Zoroastrianism were played an important role. The most important, we could meet prohibiting technological culture or restricting the actions and penalties for human being moral norms, developed legal mechanisms in these sources.

The development of the society in the next historical period: social, economic, political, and cultural relations differentialzing, integration and globalization processes unit was caused to the structure of technogen culture, its activities anthropotechnogen were done in concrete. Nowadays, this system is getting legal status for the further development of the society, the severity of subjective factors - in all spheres of factors of technologic human.

We will recognized that in our history of human civilization, culture in general, especially on the basis of determination of technological civilization of technological culture, it is relatively common and preferred definition, or: "the collection of the culture - the nature of human, change of environment and economic and spiritual wealthy during the change process and rebuilding this wealthy and its rebuilding methods and styles" [2, 104]. Thus, this comment was importance with the classic sense and the complex-systematic.

It requires to "edit" it is description on the reason of the historical development of the cultural phenomenon of the paradigm of society and changes of functional status, new features, reflected qualities. Present aggravation of the current global problems, to be not changed the environment by human in its definition, but it consists of rebuilding and protecting them. Technology culture to define current stage of development and in the rising system was not accidental. So, the functional principle of technological culture must be assessed on the following methodological factors.

In our opinion, technogen civilization is one of the developing stages which consists of realization of potential possibilities, using factors and technologic styles which was directed to economic life of the present and future generations of specific nation, state and world culture. While giving the definition of technological civilization in general: it has a connection between human and social relationships of technological culture, it must be paid attention in its essence, the functional significance of the origin of the transformation method tools [3]. However, at any technological civilizations performance were independent, even if it was unique, the general public, social, economic, political and cultural relations divorces were formed and developed.
Civilizations property of accumulated technological culture was: on the one hand, human is the result of intellectual potential, science, engineering, development of technology. It must be real opportunity and objective condition of ensuring the stability of society. On the other hand, the present technogen civilization were developed the infrastructure and influence of method-factors communication of human mind, current life style "pressure of information", "mass culture", with the strengthen its threats of morality had been aggravated the social and political contradictions of society. Therefore, to eliminate them became one of the current global problems and civilization in general, and in particular caused errors which were the made in the history of civilization were briefly analyzed, it was allowed to define the objective of assessing the effects of socio-political and ideological-theoretical basis.

It is necessary, it was explained by to determine the spiritual appearance of the society, its marginalizing and being far from the nation, negative influence of life style, human mind which were the subjects technological civilization at any stages of historical development of human history. But, the development of human society, rising the level of these events escalation, it is extending its influence areas, it is put new strategic tasks to fight against them.

If we approach the solution of global problems of human being of technological civilization in the context the level of interest results will be: Firstly, it will be created technological culture system of universal theoretical and methodological basis, transformation of positive results, of the solution of negative effects; Secondly, it requires any field of science was directly or indirectly related to tecnogen civilization and technogen culture, their integration general philosophical theoretical and methodological basis; Third, it was defined individual influence direction of the globalization of technogen civilization to the technological culture and their functional significance and modern trends; Fourthly, if it was looked as a factor of approaching technological culture of special subject it would be concretized the functional relation between technological civilization of it; Fifth, the status of the disciplines in the field of technological civilization will be developed and it will become the factors which create in determining the level of other elements "intellectual discipline"; Sixth, In the influence of technogen civilization will be signed various fields of science, integration of social consciousness, the development of new technological directions of culture and development trend; Seventh, international transformation of the result of manmade global technological civilization and culture were created its methods and tools aimed at improving science. 
The main objective of the study the impact of technological culture to the globalization of technological civilization was to formulate a scientific outlook of people. Because, it determines technological, scientific worldview and their spiritual transformation (or even material life) and plays an important regulatory function. At the same time, it will be seen in the impact of technological culture caused damage to the universality of the complexsystematic and other cultural forms of reintegration opportunities. However, the possibility of this process and its role of determining could be lead to confusing conclusions. For this reason, the human nature of things antropotexnogen attitude were caused the formation of the technogen thinking and culture of the importance of knowledge-oriented system, as well as other conditions, the subjective factors will be depended on an objective assessment of the role.

At the same time, the opportunity of technictechnologic influence of human in the main issue of "nature-society-man" attitude was to recognize the factors that ensure the stability of the system. Because the current socio-political system to enhance the role of the human factor in the stability of its technological thinking and culture was directly related to the level of technological development, it must be seen as an important sign of civilization. In fact, the growing role of the human factor, having objective social nature and its level of development was one of particular importance in the history of man civilization. In this process: on the one hand, people meet their physical and spiritual needs of technical and technological capabilities. But, on the other hand, it isn't given positive results all the time. Therefore, it was arisen for the purposes of technicaltechnological development level seem to understand the need for rational use of the role of the human factor related to alternative concepts.

Various interests, even if it was based on common concepts, technological civilization to solving the negative effects of globalization and to recognize the importance of the role of the human factor was very important. In particular, a person's "technological moral qualities" of things antropotexnogen impact of management by raising the issue of unity is observed.

The development of internal and personal quality of person, social transformation and to ensure the development of civilizations were formed on the basis of ideas of improving a person's self-concept "performance revolution in the mind" in the concept "New humanism" of Roman club which created and developed in the West in the $60-70^{\text {th }}$ of the twentieth century [4, 211].

In general, there were two directions seen in the relations of "Club of Rome" strategy of technogen civilization: At first, it as allowed to refuse "false optimistic" technocratic illusion about the future of our society and to use "shock therapy" to make people think about the real state of the world; the second: to move to the change a common global problems from particularly technological civilization of the results of the quantitative analysis, which is the main object and the subject of human nature, to manage of the purpose and spiritual values of the rational system.

In fact, all of the positive results which is achieved in various stages of human history (different futurologic: optimistic, pessimistic, skeptical, alarmistic, despite of fatalistic approaches), technological civilization, technological culture and human activity was the result of conscious control, it helps to determine its status in society, the nature of social relations, targets and to determine the value of targets.

Today, the international community's attention derivatives of human technological civilization "mass culture" in relation to the threat, to focus the formation of active citizenship, social and political position was one of the global problem. Accordingly, the international political community and the scientific community of mankind "mass culture" of globalization were warned about the threat of a serious crisis. "In particular, currently the world's growing spiritual challenges, "mass culture" to protect the minds of our children from the harmful effects of science and culture community, the role of art and the role is growing" $[5,133]$. Because this illness is being influenced by a person's dependent and marginalizing. Among young people to go to the severity of the crime, norcomania, drugs and nigilistik attitude to the historical heritage, unethical behavior is caused "mass culture" escalation. It was spreading new anthi-humanistic social dangerous, "virus", non-moral "infections" among those social life. Pedagogical-didactic function of moral values in technogen civilization which created in the history of their prevention is very important. Because, it should have a certain theoretical knowledge and practical skills of the education system in to overcome the threat of them and every citizen should understand the meaning of "mass culture".

In this occasion, the grows of the persons requires of humanistic, cultural and civilization relations to the social life have been grown and the criteria has been changed. These requirements are as follows:

- to get ready for a high probability of extreme events which create technogen civilization on bases of historically formed humanistic and moral values and legal norms;

- to have active civil position on the basis of organization and implementation norms and democratic principles of technogen civilization of socio-political relations system;

- the result of the foundation of the spiritual and cultural life of the nation of the technogen 


\begin{tabular}{l|lrl|l|ll} 
& ISRA (India) & $=\mathbf{1 . 3 4 4}$ & SIS (USA) & $=\mathbf{0 . 9 1 2}$ & ICV (Poland) & $=\mathbf{6 . 6 3 0}$ \\
Impact Factor: & ISI (Dubai, UAE) $=\mathbf{0 . 8 2 9}$ & PUHL (Russia) $=\mathbf{0 . 1 7 9}$ & PIF (India) & $=\mathbf{1 . 9 4 0}$ \\
& GIF (Australia) & $\mathbf{0 . 5 6 4}$ & ESJI (KZ) & $=\mathbf{1 . 0 4 2}$ & IBI (India) & $=\mathbf{4 . 2 6 0}$ \\
& JIF & $\mathbf{1 . 5 0 0}$ & SJIF (Morocco) & $=\mathbf{2 . 0 3 1}$ & & \\
\hline
\end{tabular}

civilization and the history of technological culture, learning their mental development laws were getting more global.

\section{References:}

1. (2016) The connection with event of "Technogen civiliztion" and "Technologic spirituality" were explained with straight and against connections' relation of them. Except them, it is count as style which marks "quality", level of producing mothods of technologic spirituality.

2. (1998) Scientific and Common Explanatory Dictionary of Independence T.: «Sharq», 1998. pp.104.

3. (2016) If it is apporoches each spheres of science and cultural in the context of this style, it can be concratized their meaning and explanation.

4. (1985) Pay attention: Pechchei A. Human quality. Pub. 2nd. Moscow: Progress, 1985. pp. 211.

5. Karimov I (2008) High spirituality is an invincible power. T.: "Ma'naviyat", 2008. pp.133.
6. Otamurodov S (2008) Globallashuv va millat. (Siyosiy-falsafiy tahlil). - T.: Yangi asr avlodi, 2008.

7. Maxkamova D (2004) Sentralnaya Aziya i strany Vostoka na puti sotrudnichestva i dialoga kultur. // Ijtimoiy fikr. Inson huquqlari. 2004. № 2. - pp.20.

8. Kuznesov V (2003) Geokultura. Osnovi geokulturnoy dinamiki bezopasnosti $\mathrm{v}$ mire XX1vek: kultura set. Moscow, Kniga i Biznes, 2003. -pp. 416.

9. Shveyser A (1973) Kultura i etika, Moscow, Progress, 1973. Etika blagogoveniya pered jiznyu Chast 2, gl. XXI. 340 p.

10. Adilxodjayeva SM (2008) Globalizasiya i vopros ustoychivogo razvitiya gosudarstva. // O'zbekistonda ijtimoiy fanlar. 2008 № 3. -pp.55. 